\title{
VETANCURT'S NAHUATL PRIMER
}

\author{
BY FRANK DAUSTER
}

Professor Dauster is a member of the Department of Romance Languages at Rutgers University.

$1 \mathrm{HE}$ Spanish priests who accompanied the first conquistadors to Mexico also became the first linguists of the New World.

1 In their missionary zeal, they learned the many languages, writing grammars in order to pass this knowledge to those who would spread out over Mexico, adapting theological allegorical dramas out of Spain's religious tradition to the conventions of the Indian theater. To them we owe the earliest information about the Indian languages, as well as some of the most detailed accounts of the customs of the great prehispanic civilizations which led Cortés's men to exclaim that there was nothing so grand in Europe as those magnificent cities.

Among the important contributions of these early philologists is a recent acquisition by the Rutgers Library, the Arte de lengua mexicana ( 1673 ) of Father Augustín de Vetancurt, a systematic grammar of Nahuatl, the language spoken by the Aztecs, and related to those languages spoken across most of northern Mexico and a large part of the southwestern United States. Vetancurt's purpose is quite clear; in addition to a grammar, the Arte includes a list of necessary phrases for priests who might have to administer the sacraments to non-Spanish speaking converts, and a complete catechism in Nahuatl. Although his purpose is religious and the organization of his book based on the European grammars of the classical languages, he was able to note a number of characteristics which are peculiar to Nahuatl.

Although Vetancurt's Arte was published I 50 years after Cortés's triumph, there was still a great need for zeal, learning and, above all, courage, for large parts of Mexico were only relatively pacified and in Yucatan, an entire Maya city was to hold out as an independent nation for another 23 years. At the same time, the sophisticated capital city was not entirely removed from the Indian millions around it, any more than were the other cities of the New World. 
As late as I7I 4 religious works were being composed in Nahuatl, and the nun Sor Juana Inés de la Cruz (r648-1695), Mexico's finest poet of the colonial period and one of the giants of the Spanish Baroque, included whole verses in Nahuatl in some of her minor poems. It is even conceivable, given the dates, that Sor Juana might have studied from a copy of Vetancurt's Arte.

The Arte is of value even today for the study of linguistic change, comparing the language as it appears in Vetancurt's grammar and as it is spoken by a large part of Mexico's population. Perhaps its greatest value is as one of the first links in the chain of contributions made by other priests, such as the I 8 th Century Jesuits who contributed so greatly to Mexican letters, and the dean of Nahuatlists, the contemporary Father Angel María Garibay. Garibay has published a number of linguistic and literary studies, but his masterpiece is the two-volume history of Nahuatl literature, a lively but scholarly work in whose pages the reader finds prehispanic texts of great metaphoric complexity and a high degree of artistic worth.

Father Garibay's work is symptomatic; the Mexican today is highly conscious of his double heritage. Among the most sophisticated and cosmopolitan of modern writers, we find a marked awareness of the Indian tradition. Miguel León-Portilla has published several long studies of Aztec philosophy and theology. Octavio Paz, one of the finest living poets in Spanish, has written Piedra de sol, an enormously complex metaphysical poem which follows the structure of the Aztec calendar as it is found in the famous Calendar Stone, and José Gorostiza's Muerte sin fin, probably the best single poem in Mexican literature, is closely based on the Toltec sacrificial ritual.

Although Vetancurt would undoubtedly have been astonished to know that his modest effort to provide religious instruction for the Indians was anything more than that, it is in fact one of the steps in a process which has produced a culture whose people speak Spanish, worship in Vetancurt's faith, and refer to the Conquest as the moment when "they" defeated "us." 